Oral Tradition, 25/1 (2010): 115-140

\title{
The History of the Closure of Biblical Texts
}

\author{
Werner H. Kelber
}

\section{Prologue}

In an essay entitled "Technology Outside Us and Inside Us" (1992), Walter Ong developed the basic principles of a media-sensitive hermeneutics that have informed my work over the years and that provide a theoretical underpinning for this paper. Writing and print, as well as electronic devices, according to Ong's thesis, are technologies that produce something in the sensible world outside us but also affect the way our minds work. Handwriting slowly undermined and partially replaced the predominantly oral lifeworld, print drastically altered major aspects of Western civilization, and the electronic medium is about to usher in a transformation of global dimensions. External changes have always been plainly in evidence, especially at epochal threshold events such as the alphabetic revolution in ancient Greece around 700 BCE (Havelock 1982), or the fifteenth-century shift from script to print (Eisenstein 1979) events that scarcely left a single sphere of human activities untouched. But, and this is Ong's point, we have not been sufficiently aware of the depths to which media technologies have penetrated the human psyche (1992:194):

\footnotetext{
Writing, print, and electronic devices of various sorts are all devised to deal, directly or indirectly, with the word and with thought itself. Of all technologies, they affect man's interior most. Indeed, in a curious way they enter into man's interior itself, directly affecting the way in which his consciousness and unconsciousness manage knowledge, the management of his thought processes, and even his personal self awareness.
}

Chirography, typography, and electronics are, for Ong, an "interiorized phenomenon, something registering inside humans" (191), affecting cognitive faculties, patterning thought processes, altering modes of discourse and research, reinforcing, complexifying, and even deconstructing reasoning processes.

For some time now my own work in biblical studies has examined ways in which our ritualized print habits of reading and writing, editing and authoring have - until recentlystylized our perceptions of ancient and medieval modes of communications. All along, a concern of mine has been to highlight the magnitude of what I have termed the typographical captivity that has shaped our methodological tools, sharpened our critical methods, and swayed our 
assumptions about ancient texts. In terms of media sensibilities it is no exaggeration to claim that print was the medium in which modern biblical scholarship was born and raised, and from which it has acquired its formative methodological habits, its intellectual tools, and, last not least, its historical theories. For all practical purposes, it was not handwritten manuscripts but the print Bible - the first mechanically constructed major book of print technology - that has served, and continues to serve, as the centerpiece of modern biblical scholarship.

Mindful of the power of media in the ancient and medieval past, in modernity and in current biblical scholarship, this paper attempts an overview of the history of the biblical texts from their oral and papyrological beginnings all the way to their triumphant apotheosis in print culture. In macrohistorical perspectives, a trajectory is observable that runs from scribal multiformity, verbal polyvalency, and oral, memorial sensibilities toward an increasing chirographic control over the material surface of biblical texts, culminating in the autosemantic print authority of the Bible.

\section{The Mouvance of Tradition}

A few years ago David Carr published an exceedingly ambitious book that discusses ways in which people in ancient Near Eastern civilizations produced, worked, and lived with texts, or, more specifically, ways in which writing and literature functioned orally, scribally, and memorially in predominantly educational contexts. In Writing on the Tablet of the Heart (2005), Carr has constructed a paradigm of the ancient verbal arts that will serve as a useful starting point for my deliberations.

Writing, texts, and literacy, Carr suggested, have to be understood as core constituents of educational processes. From Mesopotamia to Egypt, and from Israel to Greece and into the Hellenistic period, literacy and education were closely interconnected phenomena. Indeed, literacy and education were virtually synonymous as long as it is understood that neither concept conveys what it has come to mean in the print culture of European and North American modernity. Concepts derived from the contemporary experience of literacy in the West are too narrowly focused on the technical ability to read and write. In the ancient Near Eastern cultures what mattered most was the kind of literacy that went beyond alphabetic competence to include training in and mastery of the tradition. A literate person was not necessarily an alphabetically skilled individual but one knowledgeable in the tradition. Education likewise entailed more, and often something other, than training in the rudiments of writing and reading. The principal aim of education was the internalization of texts in people's minds and hearts for the purpose of generating and/or reinforcing what today we might call the cultural identity of a people. Skilled scribes were expected to possess or acquire mastery of their core writings by way of memorization and recitation. Scrolls, therefore, functioned less as reference systems or text books and more as memory devices or, to use Carr's preferred term, as instruments of "enculturation."

Carr's "enculturation" model has no counterpart in today's Western world of communications and is, I should like to claim, unlike many conventional concepts of textual 
composition and transmission currently in use in the scholarly study of ancient Near Eastern, classical, and biblical literature. Recitation and memorization, essential features for Carr's reconstruction, are predominantly unacknowledged in the historical, critical paradigm, and the oral, performative dimension is still regularly bypassed. Biblical criticism, with rare exceptions, tends to view the tradition predominantly as a literary one, imagining a tight nexus of textual interfacing, implying that oral performance was a mere variant of writing. Disposed to put the emphasis on writing and texts, the historical paradigm tends to predicate a textual world that is both constituted and constrained by literary predecessors and datable sources. ${ }^{1}$

Carr's "enculturation" paradigm seeks to capture the behavior of the ancient manuscript tradition, biblical texts included, from a new angle. A whole edifice of historical conceptual tools is at stake. Ideas formed around editing, copying, revision, and recension are all subject to rethinking and may be used only with reservation. Notions about authorship, tradition, composition, and originality or authenticity, all deeply entrenched in the historical paradigm, require reconsideration. One of the corollaries of Carr's model is that the materiality of communication as it manifests itself in the technology of writing and in the physical format and layout of writing surfaces is taken into serious account. For example, one needs to devote more critical thought to the fact that the scroll was virtually useless for strictly literary information retrieval, source critical extrapolations, reference checks, and cross-referencing. It was useful mainly to people who knew more or less what to look for, to people, in other words, who had already stored the content in their minds and hearts. In short, Carr's "enculturation" paradigm summons us to construct a new theory of the verbal arts in the ancient communications world.

There can be no question that texts were in fact subject to a high degree of literal copying; many were stored and consulted for reference purposes. And yet the notion that scribes exclusively copied extant texts in literal fashion, or juggled multiple texts that were physically present to them, is in many instances not a fitting model for the communications dynamics in the ancient world. The core traditions in particular, namely those texts that mattered most educationally, were not consistently carried forward by way of literal copying. Rather, scribes who were literate in the core curriculum carried texts as mental templates. They had ingested the tradition consisting of one or more texts and were thus able to write or rewrite the tradition without any need for a physical text. Importantly, rewriting, namely the reactivation of texts, was a hallmark of the ancient enculturation process. Thus when the historical paradigm discovers textual stratification, postulating literary sources, stages, or layers, one will in many, though not all, instances more aptly speak of compositional phases characteristic of the process of rewriting culturally significant traditions.

It is difficult to arrive at a historically valid terminology that captures the dynamics of what appears to have been a generally fluid, oral-scribal, and memorial transmission. Biblical studies in particular still lack the language to define appropriately the ancient media paradigm of

${ }^{1}$ Umberto Eco in The Name of the Rose (1983:286) has memorialized the premise of intertextuality: "Until then I thought each book spoke of the things, human and divine, that lie outside books. Now I realized that not infrequently books speak of books: it is as if they spoke among themselves." 
the interfacing of orality and scribality with memory. I have found the designation of mouvance ${ }^{2}$ helpful in describing the nature of the Jewish and Christian biblical traditions, especially in their respective initial stages. The term was initially coined by the medievalist Paul Zumthor (1990), who applied it to the manuscript tradition of French medieval poetry. Observing a high level of textual variation involving not only modifications of dialect and wording but also more substantial rewritings and the loss, replacement, or rearrangement of whole sections of a piece, he introduced mouvance to characterize this textual mobility. ${ }^{3}$ Authorial anonymity and textual mobility were, in his view, connected features. Anonymity suggested that a text was not regarded as the intellectual property of a single, individual author but was subject to recurring rewritings. By analogy, large parts of the ancient Near Eastern and Mediterranean textual tradition, including the early manuscript traditions of both the Hebrew Bible and the New Testament, may be understood as mouvance, that is, as a living tradition in a process of persistent regeneration.

\section{Jewish and Christian Textual Pluriformity}

Rethinking the Jewish and Christian biblical tradition from the perspective of mouvance, I commence with a reflection on the genesis of the Masoretic textus receptus, the normative text of the Hebrew Bible. When we study the Hebrew Bible we are handed the Masoretic text, and when we learn elementary Hebrew we are confronted with Tiberian Hebrew, the linguistic system of the Masoretic scholars who produced the text between the seventh and tenth century CE. All biblical scholars, Jews and Christians alike, grow up on the Masoretic textus receptus, a text, moreover, that was reproduced numerous times in carefully handwritten copies. We are all familiar with the conventional picture, prevalent in many introductions to the Bible, of a Jewish scribe bent over his manuscript while copying the Torah in meticulous fashion. This picture of the scribal expert, reinforced by its reproduction in countless print textbooks, continues to affect the conventional understanding of Judaism as a religion of the book. Sensibility to oral-scribal dynamics is bound to modify and certainly complicate this picture.

It is well known that prior to the discovery of the Dead Sea Scrolls no single manuscript of the Hebrew Bible/Old Testament existed that was older than the ninth century CE. With the availability of the Dead Sea Scrolls we have been unexpectedly projected back to an early state in the making of what came to be the Hebrew Bible. Written roughly between the first century $\mathrm{BCE}$ and the first century $\mathrm{CE}$, these Scrolls are a millennium removed from what used to be the oldest available copy of the Masoretic text. A past hidden from us for centuries has been lifted into historical consciousness and has facilitated a new approach to the compositional history of the Masoretic text.

2 To my knowledge, Alan Kirk (2008) was the first to apply the term to Second Temple Judaism, to early Christianity, and to the early rabbinic tradition.

3 As Zumthor described it, the medieval poetic material spread both temporally and geographically "not merely by virtue of the text's physical movements as it circulates in manuscripts or in the mouths of reciters and is handed down to posterity, but also as a result of an essential instability in medieval texts themselves" (1990:45-46). 
Scholarship had some difficulty facing up to the new textual realities that were provided by the Scrolls. How deeply it was beholden to conventional patterns of thought may be demonstrated by the example of the famous Isaiah scroll, one of the best preserved among the Dead Sea manuscripts. Millar Burrows (1955), eminent representative of the first generation of Qumran experts, observed a remarkable agreement between the ancient Isaiah scroll and its Masoretic textual version. In some cases, where the Isaiah scroll differed from the textus receptus (in terms of orthography, morphology, and lexical items), he postulated copying mistakes that pointed to an inferior textual quality of the ancient scroll. In other cases, he judged variants of the ancient scroll to be superior and adopted them as a means of amending and improving the Masoretic standard. In either case, therefore, he was inclined to evaluate the ancient Isaiah scroll not as an entity in its own right, but rather from the perspective of the established norm of the textus receptus, eager to assert that the text of the Isaiah scroll "confirms the antiquity and authenticity of the Masoretic text" (314). In short, the centrality of the Masoretic textus receptus was the criterion for scholarly judgments.

Burrows' eminent textual scholarship, one recognizes in retrospect, operated under distinct text critical and theological premises. As far as text criticism was concerned, he held that its primary objective was "to detect and eliminate errors in the text as it has come down to us, and so to restore, as nearly as possible, what was originally written by the authors of the books" (301). In different words, text criticism, in his view, was designed to recover the original text. It is a premise ill-suited, we shall see, to comprehend and appreciate the copious nature of the manuscript evidence. Theologically, he insisted that in spite of the fact that the transmission of scriptural texts has "not come down to us through the centuries unchanged," the "essential truth and the will of God revealed in the Bible, however, have been preserved unchanged through all the vicissitudes in the transmission of the text" (320). This, too, represents a position that is not well suited to face up to the nature of tradition as it appeared in light of the Dead Sea Scrolls. Burrows' premises generated an optical illusion that made us see the new textual evidence as something other than it really was.

As more and more variables of biblical texts were identified at Qumran, the notion of a Masoretic text existing in the period roughly of the first century BCE was increasingly called into question. A sense of mouvance and active transcription of tradition is ever more difficult for us to overlook. Textual pluriformity had to be accounted for as a phenomenon sui generis. Few experts have taken it more seriously than Eugene Ulrich (1999), the chief editor of the Qumran scrolls. Far from disregarding, explaining away, or rationalizing textual variability, he along with others has moved it to center stage: "The question dominating the discussion of the history of the biblical text is how to explain the pluriformity observable in the biblical manuscripts from Qumran, the M[asoretic] T[ext], and the versions" (80). Textual pluriformity is now a dominant issue.

The scholarly assimilation of the new textual evidence is still very much in progress. As a result of some fifty years of intense academic labors, however, a number of points seem certain. One, the textual condition of the Dead Sea Scrolls is not specific to that community but appears to be typical of Judaism in general at that period in history. By and large, the fuller textual evidence with regard to scriptural texts - the Dead Sea Scrolls, the Samaritan Pentateuch, the Septuagint, the New Testament, and Josephus in his dealings with scriptural materials 
- "demonstrate[s] bountifully that there were variable literary editions of the books of Scripture in the Second Temple period" (9-10). As far as the ancient scriptural traditions are concerned, variability does not represent an exceptional behavior. Two, one needs to exercise caution in stigmatizing the variants as secondary, aberrant, deficient, wild, or non-biblical. All too often, these are judgments based on the criterion of later standards of normativity. Textual pluriformity was an acceptable way of textual life at that time. Three, the textual situation at Qumran does not reveal text critical efforts in the sense of comparing and selecting variants for the purpose of arriving at a norm. The community appears to have lived in textual pluriformity. Four, there is no evidence for the Masoretic textus receptus having achieved the status of normativity in the Second Temple period. Textual pluriformity was a way of life at a time when both Christianity and rabbinic Judaism were in their formative stages. Five, the text critical search for "the original text" is not only fraught with technical, philological difficulties but, more importantly, contrary to the dynamics of the textual realities on the ground. ${ }^{4}$ Six, just as many of us have come to question the notion of "normative Judaism" prior to the Second Revolt, 132-35 CE, so will we now have to be skeptical about the concept of a single "normative biblical text" in that period. Seven, the consequences of Roman imperialism were devastating: destruction of Qumran in 68 $\mathrm{CE}$, destruction of the Jerusalem temple in $70 \mathrm{CE}$, destruction of Masada in $74 \mathrm{CE}$. The political realities at the time were anything but conducive to sustained scholarly labors aimed at accomplishing a standard text. Eight, scribes were not merely copyists loyal to the letter of the text, but creative traditionists as well. This is the point where the picture of scribes meticulously copying the Torah needs to be modified. Nine, clearly there is in Second Temple Judaism broad reference to the Law, and the Law and the Prophets, but we should not think of them as "biblical" authorities as if "the Bible" in its canonized sense had already been in existence. In the words of James Barr (1983:1), "the time of the Bible was a time when the Bible was not yet there." Not only was "the Bible" not in existence, but at Qumran, Enochic literature was no less important than Deuteronomy, and Jubilees just as vital as Isaiah. Ten, we can be certain that in the Second Temple period two or three textual editions of the Pentateuch were in circulation. But when we accord them canonical or semi-canonical status, we are probably making retrospective judgments reconfiguring history according to later developments and categories.

Perhaps the Qumran evidence may be assimilated into a new historical paradigm as far as the relations between the Masoretic norm and scriptural (rather than biblical) traditions were concerned. Instead of imagining a densely intertextual web with the Masoretic text at center stage and biblical manuscripts gravitating toward it, we might envision multiple scriptural versions, including what came to be the Masoretic norm, finding their hermeneutical rationale in recitation, oral explication, and memorization, with some textual bodies such as the Pentateuch and prophetic literature assuming authoritative significance.

It is in the context of this scribal, scriptural environment of textual mouvance that we will have to grasp the early Jesus tradition as an insistently pluriform phenomenon. In terms that are sensitive to media realities, one might say Jesus of Nazareth presented himself as a vocal,

${ }^{4}$ Ulrich (1999:15) has raised a crucial question for the reconceptualization of the project of text criticism: "should not the object of the text criticism of the Hebrew Bible be, not the single (and textually arbitrary?) collection of Masoretic texts of the individual books, but the organic, developing, pluriform Hebrew text- different for each book-such as the evidence indicates?" 
rhetorical authority. Viewing him as an aphoristic, parabolic teacher, historical critical scholarship has made great efforts in retrieving the ipsissima verba, his so-called original sayings. Let us see how the search for the original sayings looks from the perspective of genuinely oral sensibilities. When Jesus, the aphoristic, parabolic teacher, recited a story or saying at one place, and then journeyed to another place to recite, with audience adjustments, that same story or saying to a different audience, this second performance cannot be understood as a secondary version, or copy, of the original rendition. Rather, the second rendition is as much an authentic performance as the first one. This suggests that the notion of the one original word makes no sense in oral performance. Likewise, the concept of "variants" is problematic as far as oral performers in the ancient world are concerned because there is no one "original" from which variants could deviate. In the predominantly oral culture in which Jesus operated, each oral rendition of a story or saying was an original, indeed the original. While historical critics are inclined to sift through the textual tradition in search of the one original, oral culture operates with a plurality of originals. More is involved here than a mere change from singular to plural. The coexistence of multiple original renditions suggest equiprimordiality, a principle that reflects cultural sensibilities that are quite different from and contrary to the notion of the one, original speech. One of the first Western scholars to conceptualize the notion that in oral tradition there was no such thing as an original rendition and variants thereof was Albert Lord (1960:101).

The early chirographic rendition of the Jesus tradition, no less than the scribal tradition preceding the Masoretic text, is characterized by a remarkable pluriformity. In both instances, fixation on an assumed textual normativity or originality has blinded us from grasping and appreciating the existent scribal tradition in its own right and on its own terms. As far as the early papyrological evidence of Jesus sayings is concerned, it appears to be characterized by fluidity rather than by foundational stability. The text critic David Parker (1997:188) has stated the case provocatively: "The further back we go, the greater seems to be the degree of variation ...." Parker adds that this situation is "not an unfortunate aberration" but rather "part of the way in which they [the Christian scribes] copied their codices" (idem). While his is not the only way to explain the phenomenon of scribal fluidity, Parker's observation nonetheless appears at variance with historical critical premises about tradition. While historical and textual criticism by and large operates on the assumption of a foundational text at the beginning, the actual scribal evidence on the ground suggests pluriformity at the outset and something akin to a foundational text at a later, secondary stage in the tradition. The analogy to the early history of the textual tradition of the Hebrew Bible is striking.

If, by way of an example cited by Parker (75-94), one sifts through the papyrological evidence of Jesus' sayings on marriage and divorce, one recognizes that the problem is not simply one of explaining the differences among Mark 10, Matthew 5 and 19, and Luke 16, an issue well known to biblical scholars. Assessment of the full scribal evidence confronts us with both an amount and degree of variability that goes far beyond Markan, Matthean, and Lukan adaptations and is not readily explicable by a single textual genealogical tree that would take us back to the one root saying. The recovery of the original rendition would seem to be an unattainable goal. In Parker's words, "a single authoritative pronouncement [by Jesus on marriage and divorce] is irrecoverable" (183). Perhaps one should add that the project of retrieving the single original saying is contrary to the intentions of the tradition. We have no 
excuse for reducing the tradition to simplicity where there is complexity, and for claiming single originality where there are multiple originalities.

It is worth noting that the reason for the mouvance of the Jesus tradition is not that these sayings were considered unimportant. To the contrary, as Parker rightly observed, the "basic reason for the complexity in the passages [on marriage and divorce] . . and in many others of Jesus' sayings is precisely the importance accorded them" (75). Issues pertaining to marriage, divorce, and remarriage have been pressing ethical concerns in the past as much as they are urgent matters for our modern churches. But it is precisely the great importance attributed to these matters that accounts for the variability in the rendition of the sayings tradition. In Carr's terms, texts that mattered most in terms of educational knowledge and cultural identity were most likely to be subject to frequent rewritings. It was precisely because of the ever-present relevance of sayings on marriage, divorce, and remarriage that a verbatim transmission was not the most desirable mode of securing the tradition. To transmit Jesus' word(s) faithfully meant to keep them in balance with social life, needs, and expectations. In paraphrasing a statement by Ong (in response to a student's question as to why Jesus did not resort to writing), one might say that his (Jesus') sayings were considered far too important to be frozen into scribal still life.

It is easier to explain, Parker observed, what the early Jesus tradition is not, and "harder to find a suitable language to describe what it is" (200). If we say that this tradition eschewed stability, we have characterized it negatively from the point of view of later developments. If one describes it, with Parker, as a "free" and "living" tradition (188), one has arrived at an appropriately positive definition but still lacks explanation for the phenomenon. In a footnote, Parker himself adduces Ong's observation that manuscripts "were in dialogue with the world outside their own borders. They remained closer to the give-and-take of oral expression" (1982:132). The validity of Ong's remark manifests itself with particular force in the case of the early scriptural traditions of both the Hebrew Bible and the Jesus tradition. When viewing the early scribal tradition of Jesus sayings from the perspective of oral-scribal dynamics, it appears to be operative at the intersection with speech, or, more precisely perhaps, it has every indication of being enmeshed with and empowered by oral dynamics. In four ways at least, this early scribal tradition functioned in keeping with the oral, performative sensibilities: first, like oral performance, the early scribal tradition was made up of variables and multiforms; second, it was constituted by plural originals rather than by singular originality; third, it sought, despite its chirographic materiality, to stay with the flux of temporality; and fourth, it enacted tradition that was not transmission per se, but composition in tradition. Both in terms of compositional intent and audience adjustment, the early scribal tradition of Jesus sayings still operated according to basically oral dynamics.

One should take note here that the model of Second Temple scribalism, insofar as it is characterized by pluriformity and oral dynamism, has been observed in the rabbinic tradition as well. Taking advantage of the developing field of orality-scribality studies, recent books by Martin Jaffee (2001) and Elizabeth Shanks Alexander (2006) have genuinely advanced our understanding of the scribal production and transmission, recitation, and reception of the rabbinic 
texts. $^{5}$ At Qumran and in the post-70 CE rabbinic tradition, Jaffee explained, the scrolls functioned in an oral-traditional environment, where they were publicly recited and in a secondary discourse explicated. Rabbinic scribes and teachers drew on the oral-performative tradition for textual compositions that in turn were subject to re-oralization. In Jaffee's view, we should imagine the rabbinic tradition as "a continuous loop of manuscript and performance" (2001:124), which never yielded a ground zero on the basis of which the original construction of the one authentic text was recoverable. In keeping with Jaffee's approach, Alexander used the oral conceptual lens to focus not, or not exclusively, on the transmissional and interpretive processes of the Mishnah, the foundational document of rabbinic Judaism, but primarily on its "performative effect," trying "to imagine what would result from performing its materials" (2006:169). Developing a concept of the ancient transmitters of the early rabbinic materials as active shapers rather than passive tradents of the tradition, she concluded that the pedagogical benefit of the mishnaic performances lay not merely in the transmission of content but in "imparting a method of legal analysis" (171) that trained the students to practice modes of legal analysis on their own.

When set against the background of the ancient Near Eastern and Mediterranean culture of communication, the performative-chirographic dynamics of the early scriptural materials of the Hebrew Bible, the Jesus sayings, and the rabbinic tradition make good sense: by and large they were embedded in an oral biosphere where scribal-oral-scribal interfaces were the rule. It was the operative logic of these traditions to reactivate (not repeat!) themselves rather than to reach for closure. To comprehend their operations, especially in their early stages, we should think of recurrent performativity rather than intertextuality.

\section{Codex and Canon}

Undoubtedly, the well-documented early use of the codex in the Christian tradition provided a technological innovation that was to be instrumental in ushering in wide-ranging cultural changes. Many of these changes were slow in coming and not immediately effective. On the macro-level the codex paved the way for the media transfer from the chirographic to the typographic identity of the book, unwittingly mediating the Bible's eventual apotheosis in print culture. On the micro-level it served as a convenient storage place for depositing numerous texts in a single book, and provided more efficient access than the scroll. No doubt, insofar as the codex supplied the base for multiple and miscellaneous textual items in a single volume, it created the material condition for the biblical canon. However, the causal connection between codex and canon must not be pressed too far. Illustrious fourth-century codices such as Sinaiticus, Alexandrinus, Vaticanus, and the fifth-century Ephraemi Rescriptus, for examplefrequently invoked as illustrations of unified Bibles - tend to blind us into assuming that volumes containing the whole Bible were common practice. Yet, not only were these codices "not produced as one volume in our sense of the word" (Parker 1997:195), but books carrying the

5 An early driving force in approaching rabbinics from hermeneutical and oral-scribal perspectives was Fraade 1991. 
whole Bible were the exception rather than the rule in ancient and medieval history. Even complete Greek New Testaments were relatively rare. The full canonical implications of the codex were only slowly realized and in the end it was print technology that finalized the canonical authority of the Bible.

But the format of the codex had a more subtle, less widely acknowledged impact on verbal art and on human consciousness. Compared with the scroll, it provided a more stable material surface that in turn encouraged experimentation with the newly acquired writing space. Below we shall have occasion to observe how techniques for formatting and arranging materials were developed that, combined with the convenient page-turning practice, were ideally suited to focus the mind on comparative readings and cross-referencing, and to encourage habits that in turn affected the perception of texts and textually perceived traditions. Thus, in taking advantage of the book format and exploring its writing space, the codex created opportunities for textuality to come into its own. In terms of the principles enunciated in Ong's essay on "Technology Outside Us and Inside Us" (1992), cited at the outset, one could say that the codex helped interiorize textuality in ways not previously experienced.

Canonicity is a topic that has for a long time commanded wide-ranging interests in biblical studies, the history of religion, and more recently in literary criticism (Zahn 1888-92; Leipoldt 1907-08; Kümmel 1965:334-58; Gamble 1985; Hallberg 1983). It seems agreed that the canonization of both the Jewish and the Christian Bible was a process that extended over centuries. The Jewish canon came into existence roughly between $200 \mathrm{BCE}$ and $200 \mathrm{CE}$, a period that is partially synchronous with Second Temple Judaism. The Christian canon reached a semblance of agreed uniformity in the fourth century, but a dogmatic articulation of canon and canonical authority did not occur until the Council of Trent (1546 CE).

In the case of the Christian canon, something of a modern scholarly consensus about the criteria and rationale for canonicity appears to have been reached. Among the criteria, apostolicity, orthodoxy, and customary usage of texts are cited by many. The reasons for canon formation are usually seen in a defense against Marcionism, gnosticism, and Montanism. One notes that the overall argument falls along the lines of orthodoxy versus heresiology, categories that are no longer quite fashionable in current historical scholarship.

From a broadly cultural perspective one might suggest that canon formation, both in Judaism and in Christianity, has to be understood against the background of the ideational and textual pluralism that was characteristic of Second Temple Judaism. Jan Assmann (1992:103-29) has seen this quite clearly. The need for canonicity, he reasoned, arises out of the experience of an excessive textual pluralism and lack of ideational uniformity that undermine the raison d'etre of the tradition. In that situation, the canon responds to the "need to prevent that 'anything goes,' a fear of loss of meaning through entropy" ("Bedürfnis, zu verhindern, dass 'anything goes,' eine Angst vor Sinnverlust durch Entropie") (123). The selective privileging of texts, therefore, manifests a will to curtail entropy, that tendency, lodged in the tradition, toward diffusion and exhaustion of energy. To define this particular canonical function, Assmann has coined the phrase of the "Bändigung der Varianz" (idem), a taming of the phenomenon of variance. From this perspective, one may view the canon as a means of safeguarding tradition by controlling and defining it, and thereby (re)asserting the cultural identity of a people. Canonicity thus understood signified an approach to the pluriform oral-scribal tradition via selectivity and exclusivity. It 
secured cultural identity, but it did so, and this is a crucial argument of this essay, at the price of closing the textual borders. Viewed against the mouvance of the Jewish and Christian textual tradition, the creation of the canon marks a principally authoritative and unmistakably reductive move.

In highlighting early triumphs of textual rationality, we are turning to Origen's Hexapla and Eusebius' Canon Table. In the words of Anthony Grafton and Megan Williams, Origen's Hexapla "was one of the greatest single monuments of Roman scholarship, and the first serious product of the application to Christian culture of the tools of Greek philology and criticism" (2006:131). ${ }^{6}$ In the perspectives we have been developing, the Hexapla is a prime example of a sophisticated utilization of the potentials of the codex by way of experimenting with format and layout and implementing new forms of textual arrangements. It is, in the words of Grafton and Williams, a "milestone in the history of the book," even though "its form, its contents, and above all its purpose remain unclear" (87).

As the titular designation implies, the Hexapla was a codex, or rather a series of almost forty codices, that arranged different versions of the text of the Jewish Bible in six parallel, vertical columns: the Hebrew version, the Greek transliteration of the Hebrew rendition, the Greek versions of Aquila (a proselyte to Judaism), Symmachus (an Ebionite), the Septuagint (LXX), and Theodotion (a Hellenistic Jew), in that order. There is now broad agreement that what prompted the massive project of the Hexapla was the conundrum of textual pluriformity that Origen encountered. "The reason for the Hexapla," states Ulrich, "was that the multiplicity of texts and text traditions proved problematic for one espousing the principle that, because the text was inspired, there must be a single text of the Bible" (1999:225). Grafton and Williams express themselves more cautiously: "Only in its original context of almost unlimited textual and translational variety can we fully appreciate the nature and function of the Hexapla" (2006:130).

Yet, granted textual pluriformity and variability, precisely how is one to understand and appreciate the rationale for constructing the Hexapla? What did Origen intend to accomplish by undertaking a textual enterprise of such colossal proportions? From our perspective, we recognize that he was himself not as well informed about the pluriformity of textual versions and traditions as we are today. He assumed, for example, that the Hebrew text type was identical with that from which the LXX had been translated, whereas current scholarship suggests that neither the LXX nor the Masoretic text are homogeneous, and that the textual character in both traditions changes from book to book. But Origen was sufficiently aware of textual pluriformity of biblical texts to embark upon the intellectually demanding, economically expensive, and physically grueling work of selecting, reproducing, and collating six versions of the Bible. Indeed, "the complex mise-en-page of the Hexaplaric columns must have presented significant logistical challenges to the scribes who created and reproduced them" (Grafton and Williams 2006:105). Scholars generally share the view that Origen's principal purpose was a sound text that could serve as a reliable basis both for Christians themselves and for their disputes with the Jews. While this may well have been Origen's ultimate goal, it is not directly evident from the Hexaplaric arrangement. As a matter of fact, constructing a single text is precisely what he did

6 Informed sensitivity to the media dimensions of scroll and codex places the work by Grafton and Williams on Christianity and the Transformation of the Book (2006) far above the conventional philological and theological approaches to patristics. 
not do. Rather than composing a standard text, he exposed his readers to a textual pluriformity, albeit on a drastically reduced scale. Could one perhaps interpret Origen's masterpiece the way Eusebius appears to have read it - as a concession that in fact no single authoritative text could be reconstructed, ${ }^{7}$ or that it was up to readers to sort things out for themselves? Be that as it may, in juxtaposing texts one next to the other, and in inviting comparative reading, Origen constructed a textual universe that constituted a virtual counter-model to the mouvance of the performative tradition.

Origen's innovative use of parallel columns in his Hexapla appears to have provided Eusebius with a model for his Canon Tables (Nordenfalk 1938). In principle, Eusebius' tables constituted something of a numerical grid that captured all four gospels. He had divided the gospel texts into small sections and then supplied each section with a number as well as a reference to its location in the tables. The tables themselves consisted of ten columns, each carrying the section numbers marked on the margin of the gospel texts. In this way, table one numbered the sections common to all four gospels; tables two to four those sections common to three gospels, tables five to nine those common to two gospels; and table ten listed section numbers with no apparent parallels. Something else altogether was in play here than the rewriting of texts, namely the mathematization of texts. By virtue of the numerical logic, an entirely new approach to reading and understanding the four gospels was introduced. Comparative thinking across the gospel narratives was now a possibility. But it was accomplished at the price of imposing a numerical logic that enclosed the gospels into a tight system or, better perhaps, into the illusion of a closed system. What Eusebius and his staff of secretaries and notaries had constructed was a strictly documentary environment of such logical persuasion and on such perfect a scale that the mind has to remove itself from the project to discern its artificiality. The Canon Tables had no basis in the real life of the gospels nor did they leave any room for social engagement, for participation in the oral-scribal-oral loop, or for compositional involvement in memorial processes. No wonder Grafton and Williams entertained the view that Eusebius was anticipating aspects of the modern library system. His experimentation with systems of information storage, they wrote, "represented as brilliant, and as radical, a set of new methods for the organization and retrieval of information as the nineteenthcentury card catalogue and filing systems would in their turn" (2006:230).

\section{Memory and Manuscript}

From later perspectives, it is evident that codex and canon, Hexapla and Canon Tables, were harbingers of things to come. At the time, however, the cultural potential of the new formatting techniques provided by the codex was far from being fully explored. It would take centuries for the scribal medium to optimize its material resources, and for human consciousness to interiorize scribal technology. The immense textual compilations accomplished by Origen and

\footnotetext{
7 See Grafton and Williams 2006:170: "Eusebius read the Hexapla as Origen had meant it to be read: as a treasury of exegetical materials, some of them perplexing, rather than an effort to provide a stable, perfect text of the Bible."
} 
Eusebius were peak performances standing out in a culture that by and large remained heavily beholden to oral, scribal, and memorial modi operandi.

As suggested above, codex and canon did not immediately translate into a universally acknowledged authority of the Bible as a single, unified book. To the extent that textual uniformity was an essential ingredient of the authoritative Bible, medieval manuscript culture, even though it had advanced beyond the scribal technology of the Second Temple period, was by its very nature not qualified to produce identical copies because it was "of the essence of a manuscript culture that every copy is different, both unique and imperfect" (Parker 1997:188).

Moreover, throughout patristic and medieval times the Bible was operational more often in plural form than as solitary authority. Collections of the Minor Prophets, for example, or a clustering of the Psalms into the Psalter, and of the gospels into gospel books enjoyed broad usage. Missals, breviaries, and lectionaries, widely used as service books in the medieval church, tended to disperse biblical texts into lectiones. There was a sense, therefore, in which the biblical tradition in the Middle Ages was experienced more as a collection of many books and a plurality of auditions than as a single text between two covers.

One will further have to remember that for the longest part of its existence the Bible was largely present in the lives of the people as an oral authority: proclaimed, homiletically interpreted, listened to, and internalized. Nor did the oral proclamation always emanate from the Bible itself. The Book of Hours (Duffy 2006), for example, composed of psalms and biblical quotations, was often a household's sole book, known from memory by millions and recited aloud at each of the eight traditional monastic hours of the day. Duffy's claim is thus very much to the point: "If we are to understand the point of contact between people and the written word [of the Bible] in the late Middle Ages, there is no more fundamental text than the Book of Hours" (42). While the chirographic Bible was rare in the hands of lay people, much of its content flourished via the Book of Hours in the hearts of millions.

Last but not least, the Bible's authority coexisted on equal footing with that of the councils and the oral and written tradition. On theological grounds, the medieval church operated with a plurality of authorities. For a millennium and a half, therefore, there was no such thing as the sole authority of the Bible in Western Christendom. It was only with print technology, and accompanying theological developments, that a standardized text and duplication of that text was a feasible proposition. Sola scriptura, we may safely claim, was a concept technically unworkable and theologically unthinkable prior to the invention of printing.

The oral authority of the Bible brings us to the phenomenon of memory. Regarded since ancient times as the wellspring of civilized life, it was a continuing force in the Middle Ages, a period in Western history that was in fundamental ways a memorial more than a documentary culture. $^{8}$ It was by no means uncommon for people to have instant recall of biblical texts, whether they had memorized them from start to finish, or whether they were in command of a selection of passages, or merely knew a series of aphorisms and stories. Augustine stands for many theologians who were entirely comfortable in combining the rigors of the manuscript

${ }^{8}$ Credit for the modern rediscovery of the force of memory in Western civilization, from antiquity to the rise of the sciences, goes to Frances Yates' The Art of Memory (1966). Mary J. Carruthers has almost singlehandedly reconceptualized medieval studies from the perspective of memory in her classic work The Book of Memory (1990). Both books have exerted a profound influence on the humanities and to a degree on the social sciences. 
culture with the demands of memory. Peter Brown (1967) has vividly described his bookish environment: "on the shelves, in the little cupboards that were the book-cases of Late Roman men, there lay ninety-three of his own works, made up of two hundred and thirty-two little books, sheaves of his letters, and perhaps covers crammed with anthologies of his sermons, taken down by the stenographers of his admirers" (428). But the man who surrounded himself with books, many of which he had composed himself, was persuaded that the quality of his intellect was intricately linked to the powers of memory. Writes Brown: "His memory, trained on classical texts, was phenomenally active. In one sermon, he could move through the whole Bible, from Paul to Genesis and back again, via the Psalms, piling half-verse on half-verse" (254). Augustine's competence in and cultivation of memory was essential not only for his retention of knowledge and mental composing, but, in the end, for the quality of his thought. Memory and manuscript interacted in ways we can hardly imagine today.

For more than a millennium, roughly from the time of the sack of Rome $(410 \mathrm{CE})$ to the invention of printing (ca. $1455 \mathrm{CE}$ ), a general shift from oral, rhetorical sensibilities to a developing chirographic control over the organization and growth of knowledge is observable. Manuscripts increasingly became important tools of civilized life, and from the eleventh century onward an ever-growing scribal culture shaped the processes of learning. Brian Stock (1983) has meticulously documented the world of communications and cultural transformations in the high Middle Ages. It is a complex story. Oral-scribal-memorial interfacing dynamics constituted "not one but rather many models, all moving at different velocities and in different orbits" (34). There was the high culture of the papacy and monasticism, of the chanceries and diplomacy, of jurisdiction, and above all of scholasticism. Undoubtedly, those were orbits that excelled in thinking and formulating complex philosophical, theological, legal, and linguistic ideas, often with signal keenness of intellect. Theirs was a culture of written records that both benefited from and contributed to the developing chirographic communication. But one must guard against facile premises concerning links between a developing medieval documentary life and a restructuring of consciousness. The processes entailed in the interiorization of medieval scribalism are intricate, raising deep questions regarding the interfacing of the materiality of language and knowledge with mind and memory. In the most general terms, however, it seems fair to say that relentless scribal labors enhanced the textual base of knowledge; that knowledge, insofar as it was managed by a working relationship with manuscripts, was apt to become detached from the oral, traditional biosphere; that in the minds of the literate elite, "oral tradition became identified with illiteracy" (12); and that knowledge processed scribally would foster comparative and critical thought. But it needs to be restated that this mutual interpenetration of scribal technology and human thought is observable predominantly among the chirographic elite.

Thus while professional scribality began to exercise effects on mind and consciousness, and the Bible became the most studied book in the West whose language and contents permeated medieval language, literacy still remained the privilege of few, and reading and writing did not instantaneously result in literate intellectualism. And this is the other part of the complex medieval communications world: the chirographic technology was, and continued to be, a tedious, backbreaking business (Troll 1990). By typographical standards, writing one letter after the next, and word after word, was exceedingly slow work, and the time spent on completing a manuscript of average length was inordinate. And so was the price of a manuscript. The copying 
of existing manuscripts aside, the manufacture of new texts was usually the result of a division of labor. There was the dictator or intellectual initiator of a text who was frequently unable to write himself/herself. There was secondly the scriptor who in taking dictation may or may not have had an intellectual grasp of what he or she was writing. Moreover, medieval Bibles for the most part did not have chapter and verse divisions. It was only around $1200 \mathrm{CE}$ that the first chapter divisions were introduced into biblical manuscripts, and around $1500 \mathrm{CE}$ that biblical texts began to be atomized into individually numbered sections or even verses. Neither the rabbis nor Augustine, neither Maimonides nor Thomas Aquinas ever cited "the Bible" the way typographic folks do.

Nor did medieval intellectuals read the Bible quite the way we do. Reading was still widely, although not exclusively, practiced as an oral activity. To be sure, some aids to the visual apperception of biblical texts were in usage. Punctuation symbols and the beginnings of word and chapter division, initially introduced in support of oral recitation, in fact imposed a visual code that was to facilitate silent reading habits. Still, far into the high Middle Ages reading was regarded as something of a physical activity, requiring good health and robust energy. In short, reading was associated with dictation and recitation more than with private reflection (Saenger 1982; Achtemeier 1990; Gilliard 1993).

Standing in a complex communications web of chirographic technology, memory, oral recitation, and homiletic exposition, the Bible was anything but a closed book with a single sense. Augustine's hermeneutics, for example, could strictly hold to the theory of a divinely inspired and unified book of the Bible, while at the same time keeping entirely aloof from literalism. He had no patience with those who thought the Word of God was plain and obvious for all to grasp. What a misunderstanding of the Bible that was! How could one incarcerate the immense mysteries of the Book into the prison house of the single sense? Veiled in mystery as the Bible was, it served to inspire hearers and readers to reach out for newer and deeper senses hidden beneath, between, or above the literal sense. Impressively articulated in his classic $D e$ Doctrina Christiana (Robertson 1958), the seven steps of hermeneutics were less a matter of exegetical discernment and more of spiritual exercises that would take hearers from the fear of God to piety, the love of God and love of neighbor, to justice, mercy, the vision of God, and all the way to a state of peace and tranquility (38-40).

Augustine's conviction of the plural senses of the Bible was widely shared in the Middle Ages. The classic theory of interpretation that dominated large segments of Western Christendom espoused the fourfold sense of biblical texts: the literal or plain sense, the oblique or allegorical sense, the homiletical and often ethical sense, and the spiritual sense that gestured toward deeper or higher realities (Lubac 1959-64). Whether one acknowledged this fourfold sense, or merely practiced a twofold sense, or inclined toward a threefold interpretation, the spiritual sense was in all instances accorded the position of priority. That the biblical text was open to plural senses was entirely taken for granted. Such was the nature of truth that it comprised multiple senses. It was as if the experience of textual pluralism had been projected onto hermeneutics. Allen Orr's conclusion (2007) that biblical literalism appeared late in the history of Christianity, and in connection with the Reformation and the so-called Counter-Reformation, has much to commend it. And both the Reformation and the Counter-Reformation, we shall see, marked a period that was closely tied in with the print medium. 


\section{The Word Made Print}

There were intellectual forces at work in medieval culture that directed the focus toward texts and developed a textually grounded (theo)logic to unprecedented heights. Around the turn of the thirteenth to the fourteenth century William of Ockham (1285-1349? CE), a Franciscan monk from Surrey County in England whose skepticism toward philosophical realism moved the particular, the experiential, and the contingent to the center of inquiry, explored the notion of distinctiveness, including the distinctive nature of texts (Adams 1987; Leff 1975). Scripture, indeed all texts, he reasoned, were operating according to something akin to an intrinsic linguistic economy, and the operations of the mind - everybody's mind - were such that they could access the internal textual logic via the cognitio intuitiva. From the perspective of media sensibilities, we observe an intellectualism that is fully at home in the prevailing chirographic culture and thoroughly exploiting its inner resources. ${ }^{9}$ In nominalism, of which Ockham was a prominent representative, the notion began to assert itself that the full potential of biblical texts was to be found less in their oral proclamation and auditory reception than in their very own textual economy. With Ockham, the closure of the biblical text was about to receive a hermeneutical, indeed theological justification. That premise of the closed text was soon to garner powerful technological support through the print medium.

Between 1452 and $1455 \mathrm{CE}$ Johannes Gutenberg produced the first print Bible, henceforth universally known as the 42-line Bible. It is not immediately obvious why he selected a book as monumental in scope as the Bible to implement a technology that was very much in its infancy. At first glance, print's technical effects of duplication appear to point to the propagation of faith as his principal objective. But many arguments speak against it. The casting of close to 300 different characters was labor-intensive and hiked up the price of the print Bible (Ruppel 1939; Kapr 1996). Moreover, Latin, the language of the Vulgate, was no longer marketable; few people could actually read the Latin print Bible. Last but not least, Gutenberg's undertaking was not a commissioned project and for this reason required vast capital investments. Analogous to developments we observe at the launching of the electronic medium, the print medium effected the entrée of entrepreneurship into the communications world. Capitalism took hold of the new medium with a vengeance. A new technological and economic culture was emerging that was not infrequently predicated on substantial financial risk-taking. In Gutenberg's case, the print Bible brought its master no economic profit whatsoever. As is well known, he died a poor man, enmeshed in lawsuits and unable to pay his debts.

To the viewers and readers of the first major machine-made book in Western civilization, the most striking feature was sameness and proportionality. Prior to the invention of printing, sameness in this sense of complete identity had never been experienced. No one jar was like the other, and no two manuscripts were quite alike. The copies of Gutenberg's two-volume Vulgate

${ }^{9}$ Carruthers (1990:158) observed that Ockham's "whole scholarly life until 1330 was spent in the greatest of European universities, his circle the most 'bookish' of the time." When, following the papal interdiction in 1330, Ockham lived isolated in Munich, he repeatedly complained that he had been deprived of access to all the books he needed to consult. 
represented models of stunning sameness, setting the highest standards of calligraphic virtuosity. By virtue of their unprecedented spatial formatting and finality of precision they expressed a sense of unearthly beauty. Michael Giesecke (1991), who aside from Elizabeth Eisenstein (1979) has written the most comprehensive, modern work on the technology and cultural implications of print technology, has suggested that aesthetics, in particular the Renaissance ideal of beauty in the sense of complete proportionality, must have been uppermost in the mind of Gutenberg. ${ }^{10}$

Owing to the duplicating effects of typography, textual pluriformity was now being effectively challenged by the ideal of uniformity. Theology and biblical scholarship were increasingly operating in a media environment that was losing touch with Jewish and Christian textual pluriformity. One either viewed the mouvance of tradition as something that had to be remedied text critically, or one was beginning to lose sight of it altogether. In short, the notion of mouvance was supplanted by what was to become the icon of textual stability. Moreover, the Bible's complete standardization, combined with its breathtaking beauty, projected a never before visualized model of authority. Indeed, it was in part at least this technically facilitated uniformity that contributed to the Bible's unprecedented authority. But again, it was an authority that was accomplished at the price of isolating the Bible from its biosphere. The printed pages, in all their perfectly proportioned beauty, created the impression that sacred Scripture was closed off in a world of its own-uniformly spatialized, consummately linearized, and perfectly marginalized - a world, that is, where in the words of Leo Battista Alberti any alteration of any kind would only distort the harmony. Now, but only now, was it possible to visualize the premise of sola scriptura, not merely to conceptualize it theologically.

It is often pointed out that the Protestant Reformers still exhibited profoundly oral sensibilities with respect to Scripture. Sola scriptura notwithstanding, Scripture remained a living presence for all of them. Martin Luther, Martin Bucer, John Calvin, Thomas Cranmer, William Tyndale, and others spoke and wrote a scripturally saturated language because they were at home in Scripture and Scripture in them. Their respective theological positions remained fully cognizant of and sympathetic toward the power of oral proclamation. Luther never viewed his vernacular translation simply as a linguistic feat, but rather as a Pentecostal reenactment of the bestowal of the Spirit (Newman 1985:espec. 117-23). The presence of scriptural orality in the theology of the Reformers cannot be in doubt.

At least as significant, however, was the influence of the print medium. The typographic apotheosis of the Bible deeply affected the Reformers' theological thinking on scriptural authority, tradition, memory, interpretation, and numerous other features. Seven hermeneutical and theological developments, all of them in varying degrees bound up with the new medium, were instrumental in bringing about tension and conflict with the oral, scribal, memorial world of verbalization. One, the rejection of the fourfold sense of the Bible aided and abetted the rationale for the closure of biblical texts. Two, the increasingly high regard for the sensus literalis jeopardized the hermeneutical pluralism cultivated by the medieval church. Three, the repudiation of allegory - the very figure that generates worlds of correspondences-was a

10 Giesecke (1991:141-43) cites a programmatic statement concerning the Renaissance ideal of beauty by the Italian architect and art historian Leo Battista Alberti (1404-72) in De re edificatoris (Florence, 1485): "Beauty is a harmony of all component parts, in whichever medium they are represented, juxtaposed with such a sense of proportionality and connectivity that nothing could be added or altered that would not distort it" (Giesecke's trans.). 
contributing factor toward reducing biblical interpretation to intra-textual literalism. Four, the unprecedented elevation of the Bible to sola scriptura conjured up the notion of the Bible as a free-standing monolithic artifact detached from tradition. Five, Luther's premise of scriptura sui ipsius interpres had the effect of closing off the Bible into its own interior textual landscape. Six, the steady marginalization of memory effected a shifting of the interpretation of the Bible toward a fully textualized, documentary model. Seven, perhaps most ominously, the rejection of tradition, this larger-than-textual life of communal memory, disconnected biblical texts both from their vital sustenance and their performance arena. To be sure, some of these features had been anticipated, implicitly or explicitly, in the manuscript culture of ancient and medieval theology, and especially in nominalism's via moderna of the fourteenth and fifteenth centuries. One cannot make print the sole determinant of these developments. But the Word made print, namely the inauguration of the medium that "is comfortable only with finality" (Ong 1982:132), heavily contributed toward viewing the Bible as a closed book, or, better perhaps, toward fantasizing it as a closed book. Typography was a major, although not the only, factor that effectively reified the biblical texts and generated a high degree of plausibility for thinking of the Bible as an authority that was standing on its own.

No doubt, these are extraordinary developments not only with respect to the status and interpretation of the Bible, but for Western intellectual history in general. In their aggregate, they amounted to an unprecedented elevation of scriptural authority seeking to hold Scripture firmly to its chirographic space and thereby depriving it of the oxygen of tradition. It is not entirely surprising that links between the severe reductionism instituted by the sixteenth-century Reformers and nineteenth- and twentieth-century fundamentalism have been drawn. In a recent study, James Simpson (2007) developed the thesis that the Reformers were the protagonists not (merely) of modern liberalism, but of modern fundamentalism as well. He is convinced that the rise of what he calls sixteenth-century fundamentalism was intrinsically linked with the power of the high tech of the fifteenth century. Simpson is not the first one to offer observations of this kind. In the past, Eisenstein (1979) has advised us to project not merely the single trajectory of Humanism, Renaissance, and Reformation toward Enlightenment and modernity, but to acknowledge other trajectories as well. Fundamentalism in the sense of literal interpretation and inerrancy of the Bible, Eisenstein observed, while strictly speaking a late nineteenth- and twentieth-century Protestant, North American phenomenon, was in the age of Erasmus "just beginning to assume its modern form" (366). Unless we recognize this development, she stated, "the appearance of fundamentalism in the age of Darwin or the holding of the Scopes trial in the age of Ford become almost completely inexplicable" (440). Needless to say, for Eisenstein the genesis of sixteenth-century fundamentalism is closely allied with the printing press and its impact on the formatting, reading, and interpreting of the Bible. On the whole, however, Eisenstein exercised a careful balance in recognizing print's consequences for better and for worse: "The impact of printing on the Western scriptural faith thus pointed in two quite opposite directions - toward 'Erasmian' trends and ultimately higher criticism and modernism, and toward more rigid orthodoxy culminating in literal fundamentalism and Bible Belts" (366-67).

Luther, it is well known, was fully conscious of the unprecedented potential of the print medium: "Typography is the final and at the same time the greatest gift, for through it God wanted to make known to the whole earth the mandate of the true religion at the end of the world 
and to pour it out in all languages. It surely is the last, inextinguishable flame of the world." 11 We know that he was in possession of print copies of Johann Reuchlin's De Rudimentis Hebraicis, of a Hebrew Bible (first published by the North Italian Jewish Soncino press in 1488) and of Erasmus' Greek New Testament. To a large extent, therefore, his work of Bible translation was carried out with the assistance and on the basis of print materials. About Luther's translation of the New Testament while sequestered at the Wartburg Castle (1521-22 CE), Eisenstein writes: "Clearly he was better equipped by printers than he would have been by scribes during his interval of enforced isolation" (1979:367-68, n. 225). Additionally, he utilized printed copies of the Bible and the New Testament as tools for proclamation, propaganda, and polemic. But he could not have anticipated the full impact the print Bible would have on the religious, social, and political landscape of Europe. No medium escapes the law of unintended consequences, and the print medium was no exception.

The print Bible was by no means the unmixed blessing that its inventor and many of its promoters had envisioned. It effected historical developments ad bonam et ad malam partem. On one level, the rapid dissemination of the vernacular print Bible raised literacy to a level never before seen in Europe; it created a steadily growing readership and encouraged further vernacular translations. Moreover, general accessibility to the Bible posed a challenge to authoritarian control over the Bible, and fostered democratic instincts about ownership and content of the Bible. On a different level, however, "the infallibility of the printed word as opposed to the 'instability of script' was recognized even by contemporaries as a fiction" (Newman 1985:101). The serious malaise that was affecting the print business, Newman observed, was of a twofold kind: "First: printers were hasty and negligent in the practice of their trade. Second: they were concerned above all with the pursuit of profits" (102). Luther himself was increasingly disturbed that "his" printed Bible had been pirated to the point where ever more printed texts of ever poorer quality were in circulation: "I do not recognize my own books ... here there is something left out, there something set incorrectly, there forged, there not proofread" (110). In other words, the very medium that was capable of standardizing the text had set into motion a process of accelerated reproduction that resulted in textual inaccuracies. But in the mechanical medium, textual errors were likely to be multiplied a hundredfold and a thousandfold. One is bound to ask: did the new medium recapitulate, perhaps even aggravate, textual pluriformity, the very condition it had set out to overcome?

The globalizing tendencies inherent in typography were making themselves felt not only in the rapid dissemination of textual variants but in conflicting interpretations of the Bible as well. Notwithstanding its typographical orderliness, the ever more widely publicized content of the Bible became a bone of fierce contention. Among a steadily growing readership, the biblical texts were exposed to unprecedented scrutiny. Inevitably, scriptural discrepancies came to light. But whereas in chirographic culture theological controversies remained confined to a small circle of theological experts, in print culture disputes were publicized across regional and national boundaries. In this way, the new medium marketed dissension and deepened disagreements.

11 The citation is from Luther's Tischreden written down by Nikolaus Medler (1532) and cited by Giesecke (1991:163 and 727, n. 167): "Typographia postremum est donum et idem maximum, per eam enim Deus toti terrarum orbi voluit negotium verae religionis in fine mundi innotescere ac in omnes linguas transfundi. Ultima sana flamma mundi inextinguibilis." 
Last but not least, vernacular Bibles became the rallying points for national aspirations, demarcating linguistic and ethnic boundaries and contributing toward the rise of nation states. "It is no accident that nationalism and mass literacy have developed together" (Eisenstein 1979:363). While the new medium thus gave momentum to national languages and identities, it also helped draw new lines of religious and national division, and strongly exacerbated CatholicProtestant polemics. Eisenstein articulated the provocative theory of typography's unintended implication in the dissolution of Latin Christianity and the fragmentation of Christian unity, asserting that "Gutenberg's invention probably contributed more to destroying Christian concord and inflaming religious warfare than any of the so-called arts of war ever did" (319).

\section{Afterthought}

The preceding reflections oblige us to extend, however sketchily, our survey of the history of the closure of biblical texts into modernity and early postmodernism. Closed-model thinking asserted itself in a variety of seemingly unrelated phenomena, many of them of significant consequence in the intellectual history and biblical scholarship of the West. Affinities with the print medium are not directly transparent, but always present at least as a subliminal influence. No doubt, closed-model thinking was effectively countered by quantum theory, relativity theory, evolutionary thinking, a revival in rhetoric and receptionist theory, and lately by the electronic medium. But the point here is to trace connections between print and closed-model thinking.

"Perhaps the most tight-fisted pre-Cartesian proponent of the closed system was the French philosopher and educational reformer Pierre de la Ramée or Petrus Ramus," writes Ong (1977:330-31). Thanks to Ong's historically and philosophically masterful study (1958) of the thought of Pierre de la Ramée, we are now well informed about changes in the sixteenth- and seventeenth-century educational system in France and across Europe. Ramus' intellectual bent approached knowledge by way of definitions and divisions, leading to still further definitions and more divisions, until every last particle of information was dissected, categorized, and located in a closed system. Ong has dramatically described Ramism as "a quantification system which is almost certainly the most reckless applied one that the world has ever seen" (1958:203). Ramus' quantified epistemology, soon to be adopted by thousands of his followers across Europe, drove him to view all intellectual activities in spatial clusters and corpuscular units, in dichotomized charts and binary tables. "Insofar as a strong stress on closed-system thinking marks the beginning of the modern era," argues Ong, "Ramus, rather than Descartes, stands at the beginning" (1977:331). To some degree, this quantifying drive and binary logic grew out of certain aspects of medieval logic, especially nominalism, but there also exists a relationship, however subliminal, between the rapidly growing technology of letterpress printing and the relentless spatialization and diagrammatization of knowledge. Ong has seen this clearly: "The diagrammatic tidiness which printing was imparting to the realm of ideas was part of a largescale operation freeing the book from the world of discourse and making it over into an object, a box with surface and 'content' like an Agricolan locus or a Ramist argument or a Cartesian or Lockean idea" (1958:311). Whereas in oral communication words are without borders, and in the 
ancient scribal, oral, memorial culture boundaries are only beginning to be drawn, it was, again, the printed page that created the illusion that knowledge was an autosemantic world within firmly drawn borders, fully captured on visual surfaces, spatialized, linearized, hence subject to spatial, diagrammatic scrutiny.

Ramism, interacting with Humanism and Protestantism, ${ }^{12}$ and fed by the forces of typography, provided the cultural matrix for the rise of modernity's historical, critical scholarship of the Bible. It was a generally post-Gutenberg and specifically humanistic, Ramist, and Protestant intellectualism that laid the groundwork for the philological and historical examination of the Bible, namely the print Bible.

Among key features that typify the rising philological paradigm of biblical scholarship, the following four may be cited. One, print was the medium from which the text critical, philological approach to the Bible received formative methodological habits and intellectual tools. Owing to the duplicating powers of the print medium, humanistic scholars were awash in print materials - a situation that was conducive to imagining tradition on the logic of strictly textual dynamics. By and large, intertextuality was now considered a root condition of all biblical texts. Two, biblical interpretation increasingly privileged the sensus literalis sive historicus, freezing the meaning of texts in their assumed historical matrix. Rather than finding the texts' rationale in their oral explication, memorization, and reception, scholars tied interpretation to the historical locus behind the texts. Three, the use of the stemmatic method locked textual versions in a tight, genealogically conceived textual diagram. Performativity was now replaced by stemmatics. Four, humanistic editors faced textual pluriformity by seeking to secure the "original" text, even though the reconstructed archetype as a rule was more often than not a virtual text that did not correspond to any historically attested textual form. It is worth speculating that the fidelity to the putative stability of the textual archetype was driven by the desire to transcend the hazards of temporality that were endemic to textual pluriformity.

These essential components of the historical, philological paradigm came to influence, indeed to define modern biblical scholarship. It is within this paradigm that most of us in academia-Jews and Catholics and Protestants alike-have been raised and educated, a paradigm, moreover, that has kept us largely uninformed about the life of biblical texts in the ancient, orally-scribally and memorially empowered tradition.

Turning to more recent developments, what comes to mind is the narrative criticism of biblical stories that got underway in the late 1960s and has flourished ever since (Kelber 1979; Polzin 1980, 1993; Rhoads, Dewey, et al. 1999). For many of us who had a hand in it, the exploration of the narrative nature of biblical stories was an exhilarating experience. We understood the application of narrative criticism to the Bible as liberation from a long history of ideational and historical referentiality. The old dichotomies of faith versus history, theology versus narrative, history versus fiction, and kerygma versus myth, we realized (slowly but surely), were inadequate and indeed outdated as a result of the discovery of narrative logic and narrative causalities.

12 Pierre de la Ramée (1515-72 CE), a Huguenot convert from Catholicism, was murdered in the St. Bartholomew's Day Massacre. Joseph Julius Scaliger (1540-1609 CE), French classical scholar, eminent text critic and philologist, and one of the founding figures of the historical, critical paradigm, likewise converted to Protestantism. On Scaliger, see Grafton 1983-93. 
However, in shifting the interpretive model from meaning-as-reference to meaning-asnarrative, biblical interpreters were inclined to adopt features of the so-called New Criticism, the very method that had prevailed roughly from the 1930s to the 1950s in Anglo-American literary criticism. In one of the best books on the literary criticism of the gospels, Stephen Moore correctly observed New Critical undercurrents in the narrative criticism of the Bible, pointing out the irony that biblical critics had embraced the creed of the holistic nature of story at a time when literary critics generally had long abandoned it (1980:3-68).

In some quarters the tendency of narrative criticism to view biblical narratives as stable, self-referential worlds came to be regarded as evidence of a self-absorbed bourgeois mentality (Hawkes 1977:154-55). Historically more to the point is the attempt to trace the New Criticism back to Coleridge and Kantian aesthetics. But there is a media dimension to this twentiethcentury phenomenon as well. Ong has observed that the closed-model thinking characteristic of (one form of) narrative criticism was flourishing at a time in Western cultural history when the technologizing, objectivizing impact of printing had reached its peak: "nothing shows more strikingly the close, mostly unconscious, alliance between the Romantic Movement and technology" (1982:161). Centuries of interiorization of print had made it artistically desirable and academically acceptable to view texts, including narrative texts, as autonomous objectworlds.

Rice University

\section{References}

Achtemeier 1990

Adams 1987

Alexander 2006

Assmann 1992

Barr 1983

Brown 1967
Paul Achtemeier. "Omne verbum sonat: The New Testament and the Oral Environment of Late Western Antiquity." Journal of Biblical Literature, 109:3-27.

Marilyn McCord Adams. William of Ockham. 2 vols. Notre Dame: University of Notre Dame Press. Rpt. 1989.

Elizabeth Shanks Alexander. Transmitting Mishnah: The Shaping Influence of Oral Tradition. Cambridge: Cambridge University Press.

Jan Assmann. Das kulturelle Gedächtnis. Schrift, Erinnerung und politische Identität in frühen Hochkulturen. Munich: Beck.

James Barr. Holy Scripture: Canon, Authority, Criticism. Philadelphia: Westminster.

Peter Brown. Augustine of Hippo: A Biography. Berkeley: University of California Press. 
Burrows 1955

Carr 2005

Carruthers 1990

Duffy 2006

Eco 1983

Eisenstein 1979

Fraade 1991

Gamble 1985

Giesecke 1991

Gilliard 1993

Grafton 1983-93

Grafton and Williams 2006

Hallberg 1983

Havelock 1982
Millar Burrows. The Dead Sea Scrolls. New York: Viking Press.

David M. Carr. Writing on the Tablet of the Heart: Origins of Scripture and Literature. Oxford: Oxford University Press.

Mary J. Carruthers. The Book of Memory: A Study of Memory in Medieval Culture. Cambridge: Cambridge University Press.

Eamon Duffy. Marking the Hours: English People and their Prayers, 1240-1570. New Haven: Yale University Press.

Umberto Eco. The Name of the Rose. San Diego: Harcourt Brace Jovanovich.

Elizabeth L. Eisenstein. The Printing Press as an Agent of Change. 2 vols. Cambridge: Cambridge University Press.

Steven D. Fraade. From Tradition to Commentary: Torah and Its Interpretation in the Midrash Sifre to Deuteronomy. Albany: State University of New York Press.

Harry Y. Gamble. The New Testament Canon: Its Making and Meaning. Philadelphia: Fortress Press.

Michael Giesecke. Der Buchdruck in der frühen Neuzeit. Eine historische Fallstudie über die Durchsetzung neuer Informations- und Kommunikationstechnologien. Frankfurt/Main: Suhrkamp.

Frank D. Gilliard. "More Silent Reading in Antiquity: Non omne verbum sonat." Journal of Biblical Literature, 112:689-94.

Anthony Grafton. Joseph Scaliger: A Study in the History of Classical Scholarship. Oxford-Warburg Studies. 2 vols. New York: Oxford University Press.

Anthony Grafton and Megan Williams. Christianity and the Transformation of the Book: Origen, Eusebius, and the Library of Caesarea. Cambridge, MA: Harvard University Press.

Robert von Hallberg, ed. Canons. Chicago: University of Chicago Press.

Eric A. Havelock. The Literate Revolution in Greece and Its Cultural Consequences. Princeton: Princeton University Press. 
Hawkes 1977

Jaffee 2001

Kapr 1996

Kelber 1979

Kirk 2008

Kümmel 1965

Leff 1975

Leipoldt 1907-08

Lord 1960

Lubac 1959-64

Moore 1980

Newman 1985

Nordenfalk 1938

Ong 1958
Terence Hawkes. Structuralism and Semiotics. Berkeley: University of California Press.

Martin S. Jaffee. Torah in the Mouth: Writing and Oral Tradition in Palestinian Judaism, 200 BCE-400 CE. Oxford: Oxford University Press.

Albert Kapr. Johannes Gutenberg: The Man and His Invention. Trans. by Douglas Martin. Brookfield, VT: Scolar Press.

Werner H. Kelber. Mark's Story of Jesus. Philadelphia: Fortress Press.

Alan Kirk. "Manuscript Tradition as Tertium Quid: Orality and Memory in Scribal Practices." In Jesus, the Voice, and the Text. Ed. by Tom Thatcher. Waco, TX: Baylor University Press. pp. 215-34.

Werner Georg Kümmel. Introduction to the New Testament. $14^{\text {th }}$ ed. rev. and trans. by A. J. Mattill. Nashville, TN: Abingdon Press.

Gordon Leff. William of Ockham: The Metamorphosis of Scholastic Discourse. Manchester: Manchester University Press.

Johannes Leipoldt. Geschichte des Neutestamentlichen Kanons. 2 vols. Leipzig: Hinrichs'sche [Buchhandlung].

Albert Lord. The Singer of Tales. Harvard Studies in Comparative Literature, 24. Cambridge, MA: Harvard University Press. $2^{\text {nd }}$ ed. 2000.

Henri de Lubac. Exégèse médiévale: Les quatres sens de l'écriture. 4 vols. Paris: Aubier.

Stephen D. Moore. Literary Criticism of the Gospels: The Theoretical Challenge. New Haven: Yale University Press.

Jane O. Newman. “The Word Made Print: Luther's 1522 New Testament in an Age of Mechanical Reproduction." Representations, 11:95-133.

Carl Nordenfalk. Die Spätantiken Kanontafeln. 2 vols. Göteborg: O. Isacson.

Walter J. Ong. Ramus, Method, and the Decay of Dialogue: From the Art of Discourse to the Art of Reason. Cambridge, MA: Harvard University Press. Rpt. 2004. 
Ong 1977

Ong 1982

Ong 1992

Orr 2007

Parker 1997

Polzin 1980

Polzin 1993

Rhoads, Dewey, et al. 1999

Robertson 1958

Ruppel 1939

Saenger 1982

Simpson 2007

Stock 1983

Troll 1990
. "Voice and the Opening of Closed Systems." In Interfaces of the Word: Studies in the Evolution of Consciousness and Culture. Ithaca: Cornell University Press. pp. 305-41.

Orality and Literacy: The Technologizing of the Word. London: Methuen. Rpt. 1988.

. "Technology Outside Us and Inside Us." In Faith and Contexts, vol. 1. Ed. by Thomas J. Farrell and Paul A. Soukup. Atlanta: Scholars Press. pp. 189-208.

H. Allen Orr. Review of Philip Kitcher, Living with Darwin: Evolution, Design, and the Future of Faith. In New York Review of Books, August 16, pp. 33-35.

David C. Parker. The Living Text of the Gospels. Cambridge: Cambridge University Press.

Robert Polzin. Moses and the Deuteronomist: A Literary Study of the Deuteronomic History. New York: Seabury Press. . David and the Deuteronomist: 2 Samuel. Bloomington: Indiana University Press.

David Rhoads, Joanna Dewey, et al. Mark as Story: An Introduction to the Narrative of a Gospel. $2^{\text {nd }}$ ed. Minneapolis: Fortress Press.

D. W. Robertson, trans. On Christian Doctrine. New York: Macmillan.

Aloys Ruppel. Johannes Gutenberg: sein Leben und sein Werk. Berlin: Gebr. Mann. Rpt. 1947.

Paul Saenger. "Silent Reading: Its Impact on Late Medieval Script and Society." Viator, 13:367-414.

James Simpson. Burning to Read: English Fundamentalism and Its Reformation Opponents. Cambridge, MA: Harvard University Press.

Brian Stock. The Implications of Literacy: Written Language and Models of Interpretation in the Eleventh and Twelfth Centuries. Princeton: Princeton University Press.

Denise A. Troll. "The Illiterate Mode of Written Communication: The Work of the Medieval Scribe." In Oral and Written Communication: Historical 
Approaches. Ed. by Richard Leo Enos. Newbury Park, CA: Sage Publications. pp.96-125.

Ulrich 1999

Eugene Ulrich. The Dead Sea Scrolls and the Origins of the Bible. Grand Rapids, MI: Eerdmans.

Yates 1966

Frances A. Yates. The Art of Memory. Chicago: University of Chicago Press.

Zahn 1888-92

Theodore von Zahn. Geschichte des Neutestamentlichen Kanons. 2 vols. Erlangen and Leipzig: A. Deichert.

Zumthor 1990

Paul Zumthor. Oral Poetry: An Introduction. Minneapolis: University of Minnesota Press. 